\title{
Destek Olmak veya OI(A)mamak: Marka Aktivizmi Bağlamında Bir Değerlendirme
}

\author{
Ömer Aydınlıoğlu (Dr. Öğr. Üyesi)
}

iD Sivas Cumhuriyet Üniversitesi İletişim Fakültesi mr_aydinli@hotmail.com

Mert Susur (Yüksek Lisans Öğrencisi)

D Sivas Cumhuriyet Üniversitesi Sosyal Bilimler Enstitüsü mert.2184@gmail.com

Başvuru Tarihi: 12.03.2021

Yayına Kabul Tarihi: 30.04 .2021

Yayınlanma Tarihi: 30.07.2021

https://doi.org/10.17680/erciyesiletisim.895504

\section{Öz}

Yaşanan toplumsal, çevresel, ekonomik ve politik olaylar bağlamında markaların farkındalık yaratmak ve destek vermek amacıyla eyleme geçmeleri olarak tanımlanan marka aktivizmi kavramı son yıllarda sıklıkla karşımıza çıkmaktadır. Yaşanan teknolojik gelişmeler ve sosyal medya platformlarının kullanımıyla birlikte marka aktivizmi hareketleri çoğunlukla dijital ortamlarda meydana gelmektedir. Tüketiciler, son ylllarda markalardan daha duyarlı olmalarını beklerken, tutarsız davranışlar sergileyen, yanlış eylemlerde bulunan veya aksi yönde bir algıya sebep olan markaları boykot etmektedir. Marka aktivizmi kavramı çerçevesinde vaka (durum) analizi tekniğiyle ele alınacak olan bu çalışmanın amacı, marka aktivizmi bağlamında örnekleme dahil edilen Nike, Starbucks ve Netflix gibi küresel markaların \#blacklivesmatter akımına yapmış oldukları desteği ve bu desteğin tüketici kanadındaki yansımalarını masaya yatırmak ve değerlendirmektir. Amaçsal örneklem yöntemiyle seçilen ve \#blacklivesmatter hashtagi kullanılarak aktivizm hareketlerinde bulunan Nike, Starbucks ve Netflix markalarına ait vakalar çalışmanın örneklemini oluşturmaktadır. Markalar aktivizm hareketlerinde bulunmadan önce tüketicinin bu yöndeki tepkisini ön görebilmelidir. Çalışma sonucunda, marka aktivizmi hareketlerinde bulunurken kuruluşların aktivist eylem ile tutarlı davranış sergilemelerinin, şüphe uyandıracak davranışlardan kaçınmalarının ve başka bir amaç ile hareketlere dahil olmamalarının çok büyük önem arz ettiği görülmektedir.

Anahtar Kelimeler: Marka Aktivizmi, Aktivizm, Boykot, Marka Nefreti, \#blacklivesmatter. 


\title{
To Support or Not (Be Able) to Support: An Evaluation in the Context of Brand Activism
}

\author{
Ömer Aydınlıoğlu (Asst. Prof. Dr.)
}

Sivas Cumhuriyet University Faculty of Communication mr_aydinli@hotmail.com

\section{Mert Susur (MA Student)}

Divas Cumhuriyet University Institute of Social Sciences mert.2184@gmail.com

Date Received: 12.03.2021

Date Accepted: 30.04.2021

Date Published: 30.07.2021

https://doi.org/10.17680/erciyesiletisim.895504

\begin{abstract}
We have frequently come across the concept of brand activism, defined as brands taking action to raise awareness and support in terms of social, environmental, economic and politic issues recently. With technological developments and the use of social media platforms, brand activism movements generally take place on digital platforms. While consumers expect brands to be more sensitive in recent years, they boycott the brands which display incoherent behaviours, take wrong actions or cause negative perception. The aim of this study scrutinizing the issue in the frame of brand activism via case study technique is to evaluate and discuss the supports of brands to \#blacklivesmatter movement and the reflections of this support on the consumers in detail. The cases belonging to Nike, Starbucks, and Netflix, involved in brand activism movements using \#blacklivesmatter hashtag and selected through purposeful sampling method comprise the sample. Brands should foresee the consumer's reactions before taking action in brand activism. As a result of the study, it is seen that it is important for the brands to display coherent behaviours, avoid suspicious actions and not to take part in activism movements with a different purpose.
\end{abstract}

Keywords: Brand Activism, Activism, Boycott, Brand Hate, \#blacklivesmatter. 


\section{Giriş}

İnsanlık varoluşundan bu yana gerek hayatta kalmak gerekse yaşamını idame ettirmek için topluluk olarak yaşamaya gereksinim duymuştur. Topluluk olarak yaşamaya başlayan insanlar memnuniyetsizlik duyduğu olaylar karşısında daima tepkisini göstermiştir. Zamanla belli bir bilinç düzeyine ulaşmayı başaran insan bu tepkilerini kişi veya kurumlara yöneltmeye başlamıştır. Bu aktivist eylemlerin geçmişi çok eski zamanlara kadar gitmektedir. Buna karşın marka aktivizmi kavramı literatürde oldukça yeni bir kavramdır. Günümüzde yașanan teknolojik gelișmeler ve etkileșim temelli sosyal medya uygulamalarının gelişmesi marka aktivizmi kavramının gelişmesine katkı sağlamaktadır. Tüketiciler özellikle içinde bulunduğumuz pandemi dönemi dolayısıyla markalara karşı şüpheci bir yaklaşım sergilemekte ve topluma ve çevreye karşı duyarlı olduğunu kanıtlayan markaları ödüllendirmektedir. Topluma veya çevreye karşı olumsuz bir davranıșta bulunan veya yaşanan toplumsal veya çevresel sorunlara karşı sessiz kalan markalar tüketici tarafından en ağır yaptırımlara maruz kalmaktadır.

Günümüzde sosyal medyanın hayatımızda önemli bir yere sahip olması sebebiyle marka aktivizmi çalışmaları dijital marka aktivizmi halini almıştır. Dijital aktivizm hareketlerinin kısa sürede daha geniş kitlelere seslenebilmesi, maliyetin düşük olması ve kullanıcılara anında dönüt imkânı vermesi tüketicilerin bu doğrultuda dijital platformları kullanmasını sağlamaktadır. Dijital aktivizm hareketlerinde bulunan markalar, aktivizmin en önemli unsurlarından olan etkileşim faaliyetlerinin sosyal medya platformlarında hızlı bir șekilde gerçekleşmesi sebebiyle çok daha fazla sayıda tüketici üzerinde farkındalık oluşturmayı hedeflemektedir. $\mathrm{Bu}$ etkileșim faaliyetlerine katılan kullanıcılar dijital aktivist olarak nitelendirilmektedir. Dijital aktivistler markaların sosyal ve politik olaylara karşı bir duruş sergilemelerini beklemektedir. Dijital aktivizm hareketlerine katılan, sosyal ve politik olaylara karşı duruşlarını göstererek farkındalık yaratmayı amaçlayan markalar, tüketiciler tarafından takdir edilmekte veya aksine eleștiri oklarının hedefi olmaktadır.

Çalışmanın teorik kısmında aktivizm, marka aktivizmi, dijital marka aktivizmi ile ilintili olduğu kavramlar üzerinde durulacaktır. Çalışmanın araştırma kısmında ise Nike, Starbucks ve Netflix gibi örnekleme dahil edilen küresel markaların \#blacklivesmatter akımına yönelik yapmış oldukları finansal destek ve sosyal medya paylaşımlarına karşı alınan tüketici tepkileri vaka analizi tekniği kullanılarak çeşitli açılardan değerlendirmeye tabi tutulacaktır. Marka aktivizmi kavramı doğrultusunda \#blacklivesmatter hareketine destek veren Nike, Starbucks ve Netflix gibi küresel markaların destek eylemlerinin tüketici üzerindeki etkisini ve yansımasını değerlendirmek çalışmanın amacını oluşturmaktadır. Marka aktivizmi kavramı ile ilgili literatürde çok az çalışma bulunması bu çalışmanın önemini daha da arttırmaktadır. Çalışmanın kısıtlılığını ise \#blacklivesmatter hareketine destek veren ancak beklenmedik tüketici tepkisiyle karşılaşan 3 küresel markaya (Nike, Starbucks ve Netflix) ait vakalar oluşturmaktadır.

\section{Aktivizm ve Dijital Aktivizm Kavramları}

Aktivizm ve dijital aktivizm kavramlarına değinmeden marka aktivizmini ele almak mümkün değildir. Aktivizm "toplumsal dönüşüme destek olmak ya da karşı çıkmak maksadıyla gösterilen çabaların tümü” olarak tanımlanabilir (Turhan, 2017, s. 27). Bir başka tanıma göre aktivizm: Var olan toplumsal düzen içinde değişme ya da siyasal değişiklik meydana getirmek için bilinçli ve gönüllü bir biçimde yapılan eylem olarak tanımlanır (Odabaşı, 2020, s. 158). Aktivizm kavramını bu bağlamda düşündügümüzde geçmişi çok eski tarihlere dayanmaktadır. Her ne kadar tarihsel perspektiften 
aktivizmin var oluşu insanların birlikte yaşamaya başlaması sonucu ortaya çıksa da modern anlamda bahsi geçen bu hareketlerin zirve noktasına ulaşması 1950-1960’lı yıllarda olmuş ve bu yıllarda birçok aktivist hareket, kadın hakları, tüketici hakları, çevrecilik ve savaşlara karşı protestolar dahil olmak üzere üst seviyelere ulaşmıştır (Arklan \& Kartal, 2019, s. 29).

Teknolojinin hızla gelişmesi ve dünyanın küreselleşmesi bağlamında aktivizm hareketlerinde de bir gelişme yaşanmıştır. 1990'lı yıllarda internetin kullanıma girmesi ile ortaya çıkan web 1.0 kavramı web sitesi sahiplerinin insanlara sunmak istedikleri içerik ve bilgilerden oluşurken, internetin gelişmesi ve web 2.0 kavramıla internet, insanların bilgi toplama ve duygu içerikli paylaşımlarına izin vererek dünyayı birbirine bağlamanın bir yolu haline gelmiştir (Naik \& Shivalingaiah, 2009). Bu değişim, aktivizm kavramının dijital aktivizm kavramına dönüşmesine zemin hazırlamıştır. Yaşanan teknolojik gelişmeler ve bunların kullanımı aynı zamanda eski teknolojiler içinde yeni yöntemler geliştirilmesi ile ortaya çıkan yeni medya kavramı ise kullanıcıya teknolojinin içinde daha aktif olabilme imkânı da tanımaktadır (Bulunmaz, 2014, s. 25). Dijital aktivizm büyük ölçüde yeni medya ve daha spesifik olarak sosyal medya tarafından mümkün hale gelmektedir. Burada söz konusu olan yeni medya, interneti hareket halindeyken erişilebilir kılan internet ve cep telefonu teknolojisidir (Chibita, 2016, s. 71). Bu gelişmelerden yola çıkarak dijital ortamlarda ortaya çıkan her türlü aktivizm örneği dijital aktivizm olarak tanımlanabilir. Dijital aktivizm, bireylerin savundukları ya da karşı çıktıkları durumlarda, ağ yapıları ve bilgi teknolojilerinin hızlı yayılım özelliklerinden de faydalanarak ifade özgürlügüu, insan hakları ya da çevre gibi sosyal ve politik konulardaki dava, düşünce ya da olaylar üzerine eylemler tasarlayarak ortaya koymalarıdır(Özcan, 2012 s. 33 akt. Ürkmez, 2020, s. 112). Dijital aktivizm hareketlerine dahil olan bireyler ise dijital aktivist olarak ifade edilmektedir. Bireylerin her zamankinden daha fazla öğrenme, iletişim ve iş birliği yapma kapasitesine sahip olduğu bu dijital dünyada tüketiciler küresel markalara daha fazla itiraz etmeye, çevre sorunları ve insan haklarıyla ilgili kurumsal uygulamalar hakkındaki endişelerini dile getirerek gerçek bir değişim yaratmak için her zamankinden daha fazla potansiyele sahiptirler (Sivitanides \& Shah, 2011). Dijital aktivistler Facebook, Twitter ve Instagram gibi çok popüler olan sosyal medya platformları üzerinden aktivizm hareketlerini gerçekleştirirler. Çok sayıda vatandaş birbirine kolay bağlanabildiğinde, orijinal içerik gönderip alabildiklerinde ve eylemi koordine edebildiklerinde etkili siyasi hareketler yaratabilirler (Joyce, 2010, s. 2). Dijital aktivistlerin popüler olan sosyal medya platformlarını tercih etmelerinin sebebi mümkün olabildiğince daha fazla kişiye ulașmak ve etkileşim oranını arttırmaktır.

\section{Marka Aktivizmi ve İlintili Olduğu Kavramlar}

Markaların tüketiciler ile kurudukları ilişkiler ve kullandıkları stratejiler her geçen yıl değişmektedir. Tüketici ile marka ilişkisinin temelinde iletişim yer almaktadır. Marka aktivizmi siyasi değerlerle yaratılan ve sürdürülen mesajlar ve kampanyalar aracılığıyla vatandaş-tüketiciyi etkilemeyi amaçlayan bir iletişim stratejisi olarak tanımlanmaktadır (Manfredi-Sánchez, 2019, s. 343). Oldukça popüler bir kavram olan marka aktivizmi, kuruluşların değerleri ve vizyonu ile uyumluluk göstermelidir. Marka aktivizmi, şirketin sosyal, ekonomik, çevresel ve siyasal sorunlara da bir etki yaratmayı arzulaması, araması ve duruş sergilemesidir (Odabaşı, 2020, s. 161). Marka aktivizmi şirketin veya bir markanın temel değerlerini ve vizyonunu sosyal, çevresel, ekonomik ve kültürel sorunların desteklenmesi veya tanıtımı ile aynı hizaya getirmesiyle ortaya çıkan bir kavram olarak tanımlanabilir (Shetty, Venkataramaiah, \& Anand, 2019, s. 163- 
164). Kotler ve Sarkar (2017) ise marka aktivizmini "Şirketlerin mevcut ve gelecekteki toplumsal niteliklerini ve gezegenin sağlı̆̆ını önemseyen değer odaklı bir strateji” olarak tanımlamaktadır (Kotler \& Sarkar, 2017). Tanımlardan hareketle marka aktivizmi, bir şirketin veya bir markanın toplumsal, çevresel, ekonomik, kültürel ve politik sorunlar ile ilgili farkındalık yaratmak ve bu sorunlara destek vermek amacıyla harekete geçmesi olarak tanımlanabilir. Şirketlerin değerleri ve vizyonları ile uyuştuğundan tanıtım, teşvik ve iş yapma biçimlerine katkıda bulunan marka aktivizminin eylemleri arasında; kişilere, gazetelere ya da siyasetçilere mektuplar yazma, siyasal kampanyalar yürütme, ekonomik aktivizm (tercih edilen markaları, şirketleri desteklemek ya da afișe edip boykot etmek), toplantılar, sosyal medya iletişimleri kullanma, sokak yürüyüşleri, oturma eylemleri gerçekleştirme, grevler ve iş yavaşlatmaları bulunmaktadır (Odabaşı, 2020, s. 161).

Günümüzde tüketici profilinde yaşanan değişiklikler sebebiyle artık ürünün fiyat ve fonksiyonlarından ziyade, markaların toplumsal sorunlara bakış açıları daha önemli hale gelmiștir. Tüketiciler markalardan sosyal ve politik konularda bir tavır almasını ve farkındalık yaratmasını beklemektedir. Araştırmalar, markaların ve şirketlerin tüketicilerle duygusal konularda bağlantı kurma becerisine sahip olduklarında, söz konusu bağın ürün, kalite veya fiyattan daha önemli hale geldiğini göstermektedir (Kubiak \& Ouda, 2020, s. 6). Halkla ilişkiler ve pazarlama danışmanlık firması olan Edelman'ın araștırmasına göre tüm tüketicilerin neredeyse yarısı (yüzde 46'sı) markaların ülkenin sorunlarını çözmek için hükümetlerden daha iyi fikirlere sahip olduğuna inanmaktadır (Edelman, 2018). Marka aktivizmi, markaların ve şirketlerin üzerinde olumlu etkilerin yanı sıra göz ardı edilemeyecek kadar büyük riskler de barındırmaktadır. Bu bağlamda aktivizm hareketlerinde bulunan markalar boykotlarla karşı karşıya kalabilir. Markalar aktivizm hareketlerinde bulunduklarında bazı tüketiciler ile karşıt görüşte olabilmektedir. Söz konusu tüketiciler markaya ön yargılı yaklaşmakta hatta bu durum tüketicilerin markadan nefret etmesine kadar gidebilmektedir. Tüketicilerin bir kısmı markaların aktivizm hareketlerindeki amaçlarının kâr olduğunu düşünmekte ve bu markalara karşı şüpheci yaklaşmaktadır.

\subsection{Boykot ve Marka Aktivizmi}

Marka aktivizmi, tüketicilerin büyük bir kısmı tarafından desteklenen ve iyi yönetildiğinde markaya olumlu etkileri olan bir kavram olarak değerlendirilse de istenmeyen sonuçları da beraberinde getirebilmektedir. Boykot, bahsi geçen olumsuz sonuçlar arasında en sık görülenlerden bir tanesidir. Boykot, bir olaydan sonra o olayı eleştirmek ve o olayın ortadan kalkması amacıyla yapmama, kullanmama, yok sayma veya ilişkiyi kesme gibi toplu eylem sürecidir (Fidan, 2017, s. 42). Tüketici boykotunu ise Friedman, bir veya daha fazla tarafın, bireysel tüketicileri piyasada belirli satın alımları yapmaktan kaçınmaya teşvik ederek belirli hedeflere ulaşma girișimi olarak tanımlamıştır (Friedman, 1999, s. 4). Boykot kavramı 1880 yılında köylüler ve yönetici arasında çıkan anlaşmazlık nedeniyle köylülerin yöneticiyle bütün ilişkilerini kesmesi sonucunda ortaya çıkmıştır ve boykot sözcügünün isim babası emekli Yüzbaşı Charles Cunningham Boycott olmuştur (Fidan, 2017, s. 42). Boykotlar, tüketiciler tarafından desteklendikleri takdirde medyada çok ses getirmektedir. Bu bağlamda markaları zor durumda bıraktıkları bilinmektedir. Son yıllarda, Nestle'nin Afrika'da sattığı çocuk mamaları, Shell'in çevreyi kirletmesi gibi olaylara yönelik yapılan boykotlar, dünyada en çok ses getiren ve bilinen uygulamalar olarak yerlerini almıştır (Odabaşı, 2013, s. 28). Boykotlarla karşı karşıya kalan markalar, ekonomik ve sosyal olarak yıpranırken zedelenen itibarlarını eski düzeyine döndürmek için çeşitli stratejiler geliştirmek durumunda kalmaktadır. 
2018 yılında yapılan Edelman firmasının kazanılan marka araştırmasına göre dünya genelinde tüketicilerin yaklaşık 3/2'si (yüzde 64) bir markayı yalnızca sosyal veya politik bir konudaki konumu nedeniyle satın alacak ya da boykot edecektir ve bu oran geçen yıla kıyasla 13 puan yükselmiştir. İnanç odaklı alıcılar şu anda ABD (yüzde 59, 12 puan artış), Japonya (yüzde 60, 20 puan artış), Birleşik Krallık (yüzde 57, 20 puan artış) ve Almanya (yüzde 54, 17 puan artış) dahil olmak üzere pazarlarda çoğunluktadır (Edelman, 2018). Bu durumda marka aktivizmi hareketlerinde bulunan markalar, tüketicilerinde olumsuz bir algı yaratmaları halinde boykotlarla karşı karşıya kalabilmektedirler. Marka aktivizmi, markaların temel değerleri, etik ve ahlak anlayışları ve vizyonları ile uyumlu değilse, sadece reklam ve pazarlama hilesi olarak görülerek çekirdek müşteri tabanını yabancılaştırabilir. Daha da kötüsü bazen marka aktivizmi kampanyaları, farklı sosyal, kültürel, politik ve çevresel inançlara sahip müşterilerin tepkisini çekerek boykot edilmesine sebep olabilir (Shetty, Venkataramaiah, \& Anand, 2019, s. 164). Tüketiciler, sessiz kalan markaların sosyal sorunlarla ilgilenmediği algısına kapılırsa da tepki göstererek markayı boykot edebilmektedir. Bu doğrultuda, şirketler stratejilerinde sosyal konuları da göz önünde bulundurmalı çünkü tüketiciler şirketlerin sosyal sorunlarla ilgilenmediği izlenimine kapıldığı takdirde şirketleri boykot etmekten kaçınmamaktadır (Klein, Smith, \& John, 2004).

\subsection{Marka Nefreti ve Marka Aktivizmi}

Marka nefreti kavramı da tıpkı marka aktivizmi gibi literatürde oldukça yeni bir kavram olarak karşımıza çıkmaktadır. Tüketiciler ile markanın düşünceleri birbirinden farklı olduğu durumda tüketiciler markaya karşı olumsuz düşünmeye başlamaktadır hatta markadan nefret edebilmektedir. Grégoire vd. (2009) marka nefretini intikam ve kaçınma arzusu olarak ikiye ayırmaktadır. Marka nefretini, ilk olarak müşterilerin neden oldukları zararlardan dolayı firmaları cezalandırma ve onlara zarar verme ihtiyacı olarak ele alırlarken, ikinci olarak müşterilerin firma ile herhangi bir etkileşimden kaçınmaları olarak ele almaktadırlar(Grégoire, Tripp, \& Legoux, 2009. akt. Zarantonello, Romani, Grappi, \& Bagozzi, 2016, s. 8). Hegner vd. ise marka nefretini, tüketicilerin markadan hoşlanmamasının daha ileri bir boyutu olarak marka ile aralarında oluşan uyumsuzluktan, ideolojik uyumsuzluktan ve geçmişte yaşanan olumsuz deneyimlerden oluşan yoğun bir duygusal tepki olarak değerlendirmektedir (Hegner, Fetscherin, \& Delzen, 2017, s. 14). Markaya karşı oluşan olumsuz algllar ve bunun sonucunda oluşan marka nefreti, markaların aktivizm hareketlerinde yer almaları nedeniyle de ortaya çlkabilmektedir. Literatürde marka nefretinin üç olası belirleyicilerinden birincisi; tüketicilerin ürün veya hizmet performansından memnun olmamasıdır (Bryson, Atwal, \& Hultén, 2013, s. 393). Bir diğeri, öz imaj ve marka imajı arasındaki uyumsuzluktur. Sonuncusu ise tüketicilerin yasal, ahlaki ve sosyal kurumsal yanlıșları nedeniyle kabul edilemez olarak değerlendirilebilecekleri bir örgütsel davranışla ilgilidir (Hegner, Fetscherin, \& Delzen, 2017, s. 14). Marka aktivizminde bulunan markaların tüketicilerde yanlış bir algı yaratmaları veya tüketiciler ile karşıt görüşte olmaları sebebiyle marka nefreti ortaya çıkabilmektedir. Aktivist olan markalara karşı oluşan marka nefreti tüketicilerin markadan kaçınmasına sebebiyet vermektedir. Marka kaçınması ise markalar açısından hem imaj hem de değer kaybı anlamına gelmektedir.

\subsection{Tüketici Şüpheciliği ve Marka Aktivizmi}

Marka aktivizmi faaliyetlerinde bulunan markaların toplumsal ve çevresel konulara karşı destekleri ve yaklaşımları tüketiciler tarafından şüpheli bulunabilmektedir. Markaların aktivizm hareketlerinde tüketicilerin zihninde farklı bir algı yaratmaları sonucunda 
tüketiciler markaların toplumsal ve çevresel sorunlardan ziyade kâr amacı güderek aktivizm hareketlerinde bulunup bulunmadıklarını sorgulamaya başlamaktadırlar. Markalar sosyal ve politikalanlarda aktivist markalar olduklarında daha fazla incelenmekte ve tüketiciler aktivizm hareketlerinde bulunan markalara inanmayabilmektedir (Vredenburg, Kapitan, Spry, \& Kemper, 2020). Bu sorgulama ve güvensizlik sonucunda tüketici şüpheciliği kavramı ortaya çıkmaktadır. Yapılan araştırmalarda tüketiciler markaların tavır almalarını beklese de bu tür eylemlere yönelik şüphecilik 2017 yılına oranla iki kattan fazla artarak 2019 yılında \%18'den \%39'a yükselmiştir (Marketing Charts, 2019). Markalar aktif bir tavır aldıktan sonra tüketiciler, markaların genellikle işleriyle tutarsız ve alakasız olan konularla ilgilenmelerini marka aktivizminin samimi bir eylemden ziyade toplumsal trendlere bir adaptasyonu olarak algılamaktadırlar (Kubiak \& Ouda, 2020, s. 33). Gillette markası \#MeToo hareketine destek vererek cinsel tacizlere ve erkek zorbalığına karşı bir duruş göstermiștir. Bu kampanyada Gillette markası tüketiciler tarafından ikiyüzlülükle suçlanarak sosyal medyada birçok tepkiye ve boykota maruz kalmıștır. Tepki ve boykotların sebebi Gillette markasının kadınlara yönelik ürünlerini daha pahalıya satması olarak bilinen pembe vergi sorunu ile ilgiliydi (Ritschel, 2019). Gillette Markasının bu hareketi Youtube'da yaklaşık 18 milyon kez görüntülenerek 468.000 beğeni ve 901.000 beğenmeme almıştır. Birçok Twitter kullanıcısı da Gillette tıraş makinelerini çöpe atarak, parçalayarak ve uzayan sakallarının fotoğraflarını paylaşarak bir protesto ve boykot gerçekleştirmiştir (Al-Muslim, 2019). Yine benzer bir aktivizm kampanyasına imza atan Ikea markası ise farkındalık yaratmak istediği konu ile ürünleri, iş alanları ve duruşları ile uyumlu olduğundan tüketiciler tarafından Gillette markasına kıyasla gayet olumlu tepkiler almıştır. Ikea markası mağazasındaki teknolojik ürünleri kapatarak sıcaklığı 4 derece arttırdı ve müşterilerin tepkilerini ölçtü. Ikea markasının iklim değişikliği etkisi sebebiyle 4 derecelik bir sıcaklık artışının çevreye neler yapabileceği konusunda tüketiciler arasında farkındalık yaratmak amacıyla yapılan bu kampanyaya imza atarak küçük değişiklerin büyük etkisi olabileceğini vurgulayarak ürünlerindeki iklimsel ayak izini 2030 yılına kadar \%70 azaltacağını öne sürmektedir (Ikea Youtube, 2018). Birçok tüketici, marka aktivizmine katılan markaların faaliyet alanlarını ilgilendirmeyen konulara dahil olmalarının sorunlu olduğunu belirtmektedir. Gillette markası bu tutarsızlı̆̆ın ana örneklerinden biri olarak kabul edilirken, Ikea markası ise işleri, ürünleri ve dahil olduğu hareketin konusu arasındaki açık ve net bir ilişkinin iyi bir örneği olarak kabul edilmektedir (Kubiak \& Ouda, 2020, s. 33). Markalar aktivist bir yaklaşım sergilediklerinde bu yaklaşımın faaliyet alanları ile ilişkili olmaması neticesinde tüketiciler tarafından ikiyüzlülük ile suçlanmaktadır. Markaların aktivist eylemlere destek vermesi kadar tüketicilerin de desteğini alması çok büyük önem arz etmektedir.

\section{3. Çalışmanın Metodolojisi}

Çalışmanın amacı, marka aktivizmi kavramı doğrultusunda \#blacklivesmatter akımının destekçisi olan Nike, Starbucks ve Netflix gibi küresel markaların bu destek eylemlerinin tüketiciler kanadında bıraktığı etki ve yansımayı değerlendirmektir. Dıșarıdan bakıldığında iyi niyet ve yardımseverlik örneği olarak değerlendirilecek bir durumun tüketiciler tarafından farklı şekillerde algılanması ve değerlendirilmesi ve bu durumun sosyal medya üzerinde yayılması söz konusu markaları açıklamada bulunma, özür dileme vb. çeşitli eylemlerde bulunmak durumunda bırakmıştır.

Çalışmanın örneklemi belirlemek amacıyla amaçsal örnekleme yönteminden yararlanılmıştır. $\mathrm{Bu}$ bağlamda, \#blacklivesmatter hashtagini kullanarak marka 
aktivizminde bulunan Nike, Starbucks ve Netflix markaları çalışmanın örneklemi olarak seçilmişlerdir. $\mathrm{Bu}$ konu dışında herhangi bir marka aktivizm hareketinde bulunan markalar çalışmanın örneklemi dışında tutulmuştur.

Bir araştırma tekniği olarak kabul edilen vaka analizi literatürde örnek olay incelemesi, durum analizi ya da vaka çalışması gibi farklı isimler ile karşılık bulmaktadır. Örnek olay incelemesi bir ortamın, tek bir kişinin, tek bir tür dokümanın ve olayın ayrıntılı olarak incelenmesidir (Tuna \& Besler, 2015, s. 185). Bir diğer tanıma göre ise; tek bir durum veya olayın derinlemesine boylamsal olarak incelendiği, verilerin sistematik bir şekilde toplandığı ve gerçek ortamda neler olduğuna bakıldığı bir yöntemdir (Subaşı \& Okumuş, 2017, s. 420). Durum çalışması, araştırmacının gerçek yaşam, güncel sınırlı bir sistem (bir durum) ya da belli bir zaman içerisindeki çoklu sınırlandırılmış sistemler (durumlar) hakkında çoklu bilgi kaynakları (örneğin gözlemler, mülakatlar, görsel-işitsel materyaller ve dokümanlar ve raporlar) aracılığıyla detaylı ve derinlemesine bilgi topladığı nitel bir yaklaşımdır (Creswell, 2013, s. 97). Söz konusu çalışmada nitel araştırma yöntemlerinden vaka diğer adıyla durum analizi tekniği kullanılmıștır.

\section{Bulgular ve Analiz}

Çalışma kapsamında \#blacklivesmatter hareketine destek veren ancak vermiş olduğu bu destek sonrasında tüketiciler tarafından protesto edilen Nike, Starbucks ve Netflix markalarının yaşamış olduğu durumlar, vaka (durum) analizi yöntemi ile incelenecektir.

\subsection{Nike}

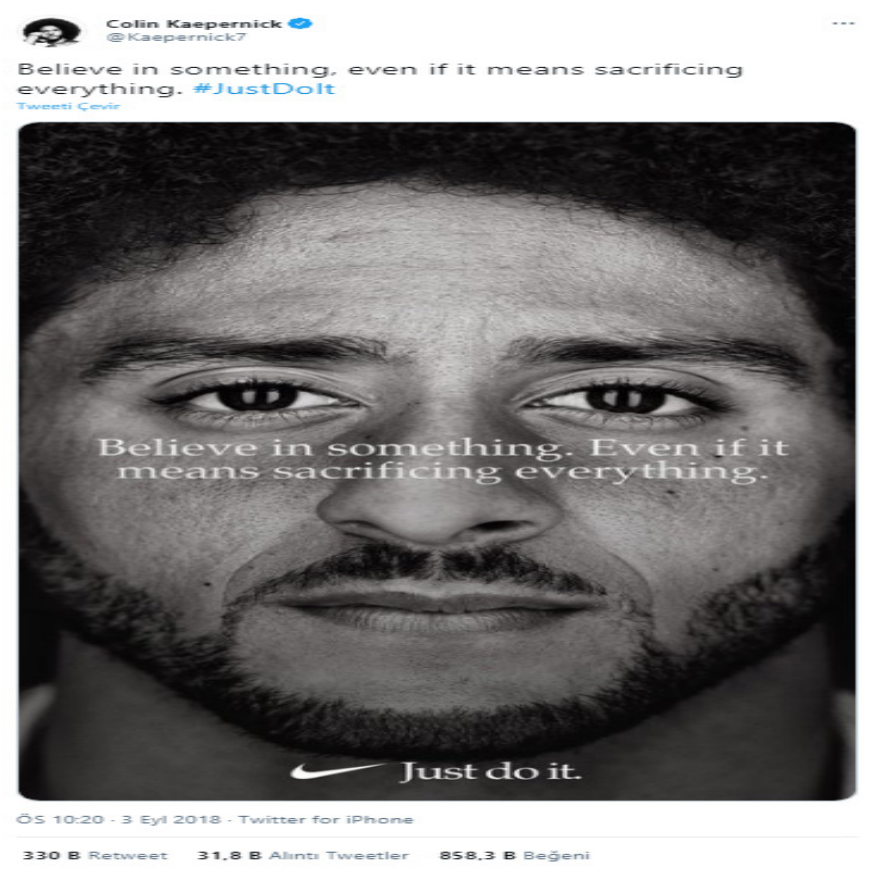

\section{Şekil 1}

Kaynak: https://twitter.com/Kaepernick7/status/1036695513251434498

Son yıllarda Amerika Birleşik Devletleri'nde siyahi vatandaşlara karşı ırkçılık ve şiddet içerikli olayların artmasının ardından ünlü Amerikan Ulusal Futbol Ligi (NFL) oyuncularından Colin Kaepernick 2016 yılında bir NFL maçında ulusal marş sırasında diz çökerek polis şiddetine ve ırkçılığa karşı çıktığını göstermişti (Beydoun, 2018). Kaepernick, 2017 yılında bir NFL takımı olan San Francisco 49ers takımından ayrıldıktan sonra NFL'ye tekrar dönememiștir. Daha sonra protestoları nedeniyle takım sahipleri tarafından kara listeye alındığını iddia ederek dava açmıştır (Guardian Sport, 
2019). Nike markası 2018 yılında Colin Kaepernick'i reklam yüzü olarak ilan ederek \#blacklivesmatter hareketine destek verdiğini duyurmuştur. Nike, Colin Kaepernick'i Just Do It kampanyasının 30. yıl dönümünde kullanmaya karar verdiğinde bir gecede marka aktivizmi için poster çocuğu haline gelmiştir (Sarkar \& Kotler, 2018). Eylül 2018'de yayınlanan "Dream Crazy" reklamında Nike markasının yüzü olan Kaepernick ve reklamın sloganı öne çıkmıştır. (Bakınız, Şekil 1). "Bir şeye inan, her şeyi feda etmek anlamına gelse bile, sadece yap" sloganı ile Nike duruşunu göstermiştir. Ayrıca paylaşımın en çok etkileşim alan yorumlarında Nike ve Kaepernick'i "Kahraman" olarak niteleyen tüketiciler bulunurken markayı boykot ederek tekrardan satın almayacakları dile getiren tüketici yorumları da bulunmaktadır. Reklama birçok saldırı olurken reklama saldıranlar arasında dönemin Amerika Birleşik Devletleri başkanı Donald Trump da bulunmaktadır. Trump 2018 Eylül ayında Daily Caller'a yaptığı açıklamada “Nike'ın gönderdiği mesajı korkunç bularak gönderilmemesi gereken bir mesaj olduğunu düşündügünü ve bunu yapmaları için bir sebep olmadığını" söylemiştir(Guardian Sport, 2019). Nike markası \#blacklivesmatter hashtagi ile ırk adaletsizliğine karşı olduğunu marka aktivizmi ile göstererek ortaya koymuştur. Nike ve Kaepernick'e karşı oluşan tepkiler Nike ürünlerinin yakılması, parçalanması ve yok edilmesine kadar ilerleyerek \#JustBurnIt sloganı kullanılarak bir protesto ve boykota dönüşmüştür (Bostock, 2018). Protestolar ve boykotlardan sonra dönemin Amerika Birleşik Devletleri Başkanı Donald Trump "Nike, öfke ve boykotlarla kesinlikle öldürülüyor. Acaba böyle bir şey olabileceğine dair bir fikirleri var mıydı?" yorumunu yaparak Nike markasına karşı tepkisini dile getirmiștir (Green, 2018). Chadwick ve Zipp ise bu durumu, "Adaletsizliği ticari amaçlarla istismar ederek desteklediğini beyan ettiği nedenleri baltalayıp aşağılayabilir mi? diyerek sosyal adalet ve eşitliğin spor ayakkabısı üretmekle ne alakası var sorusunu akıllara getirmektedir (Chadwick \& Zipp, 2018). Marka aktivizmi, șu ana kadar hiç olmadığı kadar riskli bir durum ortaya koyarken Nike, Colin Kaepernick'i reddeden Amerikan Ulusal Futbol Ligi (NFL) takımlarına sponsor olmaya devam etmektedir (Carp, 2018). Bu durum karşısında tüketiciler Nike markasının aktivizm çalışmalarının ticari amaçlarla istismar edildiğini düşünmekle kalmamakta, boykot ve protestolarla bunu desteklemektedir. Covid-19 salgını dolayısıyla birçok işletme darbe alırken, Nike markası \#blacklivesmatter hareketini destekleme konusunda önde gelen bir şirket olması dolayısıyla tartışmasız olarak daha güçlü olarak görünmektedir. Kısa süre önce yapılan bir ankete göre, Nike'ın genel halk gözündeki itibari son iki yılda güçlenmiş ve markanın elçisi olan Colin Kaepernick'in yer aldığı reklamlara ilgi yeniden artmıştır (Uhler, 2020). CBS News raporuna göre Nike markasının piyasa değeri eski NFL oyuncusu Colin Kaepernick'i yeni reklamına dahil etmesi konusundaki tartışmalı kararından bu yana 6 milyar dolar artarak tüm zamanların en yüksek seviyesine çıkmıştır. Hisseler yıl içerisinde \%36'nın üzerine çıkmış ve reklamın yayınlanmasından bu yana ise yaklaşık \%5 artmıştır (Reints, 2018). 


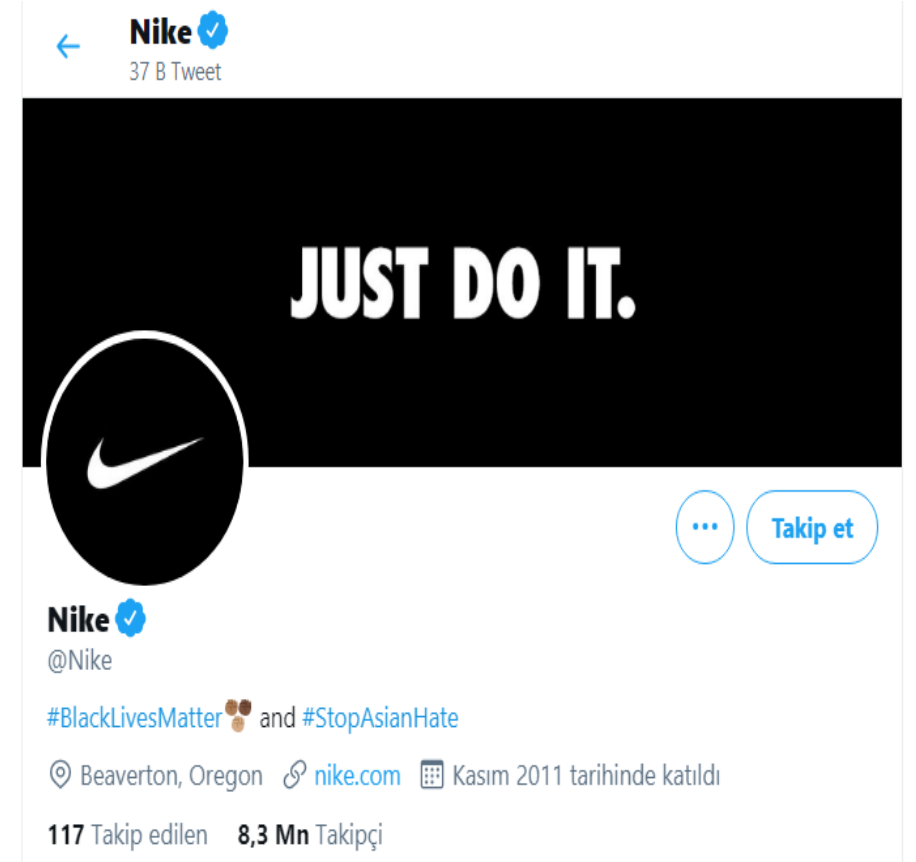

Sekil 2

Kaynak: https://twitter.com/nike

Nike, hareketi desteklediğini açıkladıktan sonra resmi Twitter hesabına \#BlackLivesMatter hashtagini sabitledi (Bakınız Şekil 2) ve harekete verdiği desteği "Bir şeye inan, her şeyi feda etmek anlamına gelse bile, sadece yap" sloganıyla perçinlemiştir. Nike \#blacklivesmatter hareketine yönelik Colin Kaepernick'i reklam yüzü olarak seçerken büyük bir risk almış ve bu hareketiyle tüketicilerin bir kısmının desteğini alırken, bir kısmının ise tepkisini çekerek olumsuz eleştirilere sebep olmuştur. Dahası, tüketicilerden yükselen tepkiler, boykotlar ve protestolara rağmen marka değerini arttırmayı başarmıştır. Nike göstermiş olduğu tutarsız davranış (Colin Kaepernick'i kara listeye alan NFL takımlarına sponsor olmaya devam etmek) ve gelen tepkilere (protestolar ve boykotlar) rağmen pazardaki yerini korumakla kalmamış marka tüm zamanların en yüksek değerine ulaşmayı başarmıştır. Tüketiciler içinde bulunduğumuz çağda artık markalardan toplumsal, çevresel ve politik olaylara karşı bir duruş göstermelerini beklemektedir. Marka \#blacklivesmatter hareketine katılarak tüketicilerin gözünde toplumsal ve politik olaylara karşı ilgili, toplumu önemseyen ve ırksal eşitsizliğe karşı net bir duruş gösteren bir marka olarak imaj ve itibarını daha da güçlendirmiștir. 


\subsection{Starbucks}

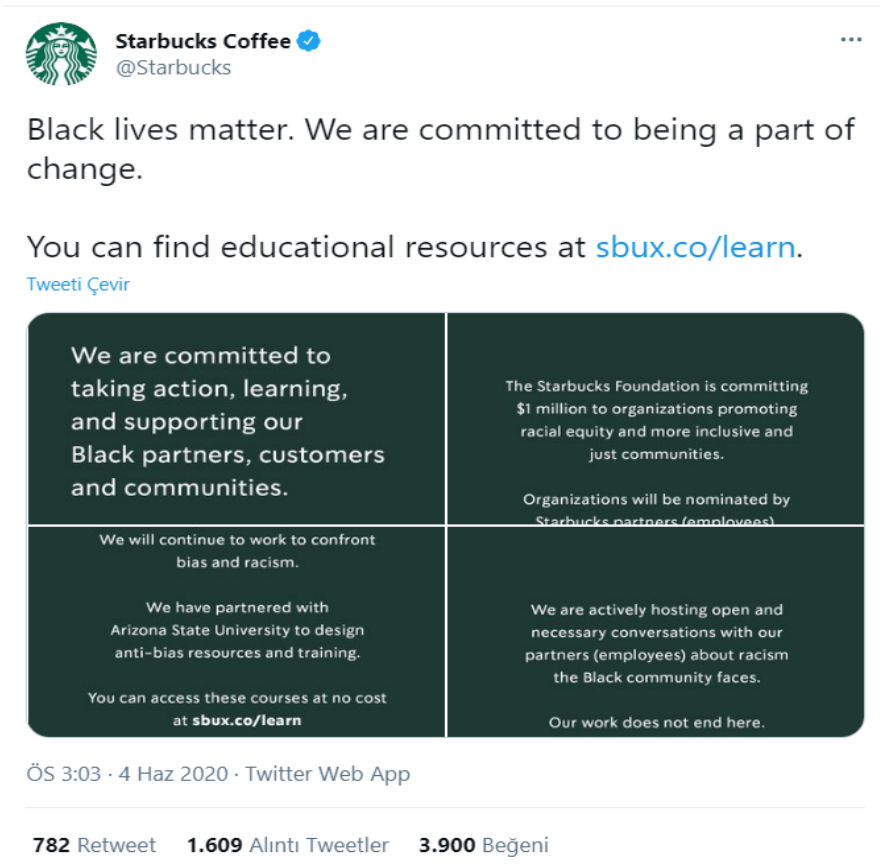

Sekil 3

Kaynak: https://twitter.com/Starbucks/status/1268513794172411905

Dünya'nın en büyük kahve zincirlerinden biri olan Starbucks markası da Amerika Birleşik Devletleri'ndeki olaylara karşı sessiz kalmayarak aktivizm hareketine dahil olmayı seçmiştir. 2018 yılında bir Starbucks çalışanının, Philadelphia'da iki siyahi adamı kahve almayı ve dükkândan çıkmayı reddettikleri için izinsiz girdiklerini söyleyerek tutuklatması sosyal medyada viral olmuş ve çok fazla eleştiri toplamıştır. Bu olaya yanıt olarak Starbucks, ırkçı önyargı eğitimi vermek için Amerika Birleşik Devletleri'ndeki tüm mağazalarını bir öğleden sonra kapatmıştır (Aratani, 2020). Bu olayın ardından tüketiciler markaya karşı şüpheci ve ön yargılı olarak yaklaşmaya başlamıştır. Amerika Birleşik Devletleri'nde polis şiddeti sonucu hayatını kaybeden George Floyd'un ardından ırkçılık karşıtı gösterilere Starbucks markası \#blacklivesmatter hashtagi ile dahil olmuştur. 1 Haziran'da kahve perakendecisi Starbucks Twitter'da “Siyahi ortak, müșteri ve topluluklarla dayanışma içinde olma” sözü vermiştir. Birkaç gün sonra \#blacklivesmatter hashtag'ini desteklemek için önyargı ve ırkçlıkla yüzleşmek ve değişimin bir parçası olmak için daha derinlemesine bir bağlllık tweeti atmış ve ardından tweeti sabitlemiștir (Sack \& Samaha, 2020). Yayınlanan tweette Starbucks markası "Siyahi ortakları, müşterileri ve toplulukları desteklemeye, öğrenmeye ve eyleme geçmeye hazır olduklarını, ırksal eșitsizliğe karşı mücadele eden kuruluşlara 1 milyon dolar bağış yapacaklarını, önyargı ve ırkçılığa karşı olmak için Arizona Eyalet Üniversitesi ile eğitim ortaklığı kurulduğunu ve değişimin bir parçası olmaya kararlı olduklarını" belirtmiştir (Bakınız Şekil 3). Starbucks, ilk paylaşımında (Bakınız Şekil 3) tüketicilerin Starbucks markasının tarafsız olması gerektiğini, \#blacklivesmatter hareketine karşıt olan gruplara bedava kahve vermeyi bırakması gerektiğini ve yapılan bağışın Starbucks gibi bir firma için az olduğunu dile getiren yorumlarla karşılaşmıştır. Starbucks markası bu paylaşımlarından sonra çalışanların hareketi destekleyen aksesuarları, tişörtleri ve rozetleri giymelerini, şirketin kıyafet kurallarını ihlal ettiği gerekçesiyle yasakladığını söyledi. Fakat şirket bunu yaparken LGBT hareketine destek veren iğne ve rozetleri bu durumdan muaf tutmuștur. Bunun üzerine Starbucks sosyal medyadan yükselen tepkiler ve boykotlarla karşı karşıya kalmıştır (Aratani, 2020). Starbucks markası daha sonra bu tepkilere ve boykotlara yanıt 
olarak Starbucks çalışanlarının üniformalarına \#blacklivesmatter sembolleri takmasını yasaklayan durumu tersine çevirmiştir. Çalışanlar sadece \#blacklivesmatter hareketini desteklediklerini ifade eden tişörtler, rozetler ve isim etiketleri giymekle kalmamış, Starbucks kendi \#blacklivesmatter tişörtlerini bile tasarlayarak ülke çapında 250.000'den fazla çalışana dağıtacağını açıklamıştır (Bakınız Şekil 4) (Segran, 2020). Starbucks, Şekil 4'te bulunan gönderinin devamında tişört tasarlamalarının harekete katıldıkları anlamına gelmediğini ayrıca satın almayacaklarını dile getiren ve ilk paylaşıma gönderme yaparak "çalışanlarınıza buraya \#blacklivesmatter aksesuarlarıyla gelmeyin dediniz bugün de görüyor, duyuyor ve destekliyorsunuz dün neredeydiniz?" gibi tüketici yorumlarıyla karşı karşıya kalmıştır.

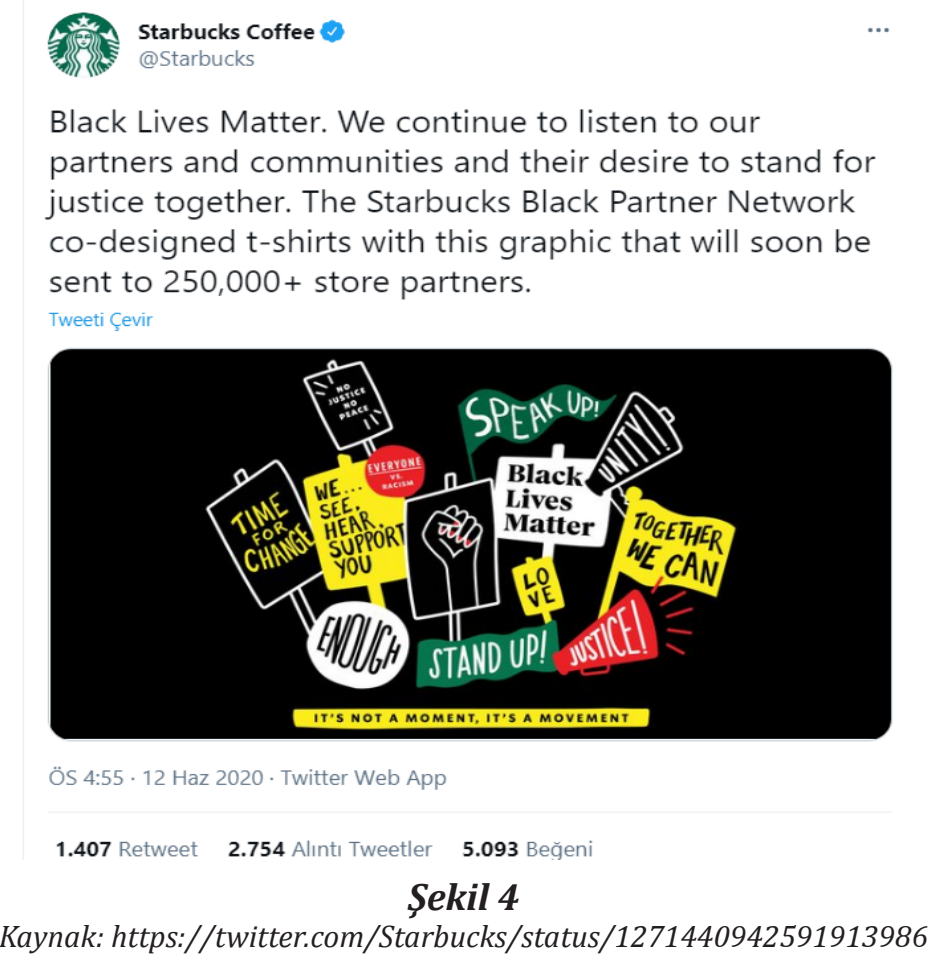

Starbucks, çalışanların \#blacklivesmatter hareketlerine destek vermek için giymek istedikleri hiçbir şeye izin vermemiştir. Fakat tüketicilerden gelen tepkiler üzerine yönetim geri adım atmıştır. Bu eski model PR ve pazarlamanın sonuna geldiğimizin ve markaların sahibinin yöneticiler değil de insanlar olduğunun bir kanıtıdır. Onlar için kulaklarını tıkamak gibi bir lüks ve kibir söz konusu değildir (Adıyaman, 2020). Starbucks ilk önce kıyafet yönetmeliği ihlali olacağını söyleyip \#blacklivesmatter tişört ve aksesuarlarını yasaklamıştır. Nitekim, Starbucks çalışanlarına harekete destek vermelerine izin vereceğini söylese de bu sürede hisseleri \%15 oranında düşüş göstermiştir ancak bu olayın ardından Starbucks hisseleri sadece bir günde \%3 artmıştır (Garcia, 2020). Starbucks, sosyal ve ırksal eşitliği geliştirme misyonu üstlenerek, 2025 yılına kadar kurumsal düzeydeki çalışanların \%30’unun, perakende ve üretim görevindeki çalışanlarının ise \%40'ının siyahi, Asyalı ve Güney Amerikalı vatandaşlardan oluşmasını hedeflemektedir. Ayrıca Starbucks Vakfl, Afrika kökenli siyahi Amerikalı topluluklara hizmet eden toplum temelli kâr amacı gütmeyen kuruluşlara odaklanarak 1,5 milyon dolarlık hibe sağlayacaktır (Canbaz, 2020).

Starbucks, attığı tweette siyahi ortak, müșteri ve toplulukları desteklemeye devam edeceğini, ırksal eşitsizlik için kuruluşlara bağış yapacağını belirtmiş ve hareketi benimsemek adına Arizona devlet üniversitesiyle ırksal eşitsizliğe karşı eğitimler için 
ortaklık kurarak harekete bağlılığını göstermek istemiştir. Starbucks, attığı tweetle \#blacklivesmatter hareketine katılarak destek vereceğini açıkladıktan sonra çalışanların \#blacklivesmatter hareketine destek amaçlı kıyafet ve aksesuarların kullanımını yasaklamış ve bu hareketiyle tüketicilerin tepkisini üzerine çekmiştir. Tüketicilerin markanın hareketlerini tutarsız bulması sonucunda sosyal platformlardan tepkiler ve boykotlar yükselmeye başlamıştır. Starbucks markası daha sonra yanlışından dönmesine rağmen hisselerindeki düşüşü önleyememiş ve tüketici nezdinde itibar ve imajını zedelemiştir. Marka, hatasını telafi etmek amacıyla tüketicilerin yanında olduğunu göstermeye çalışsa da markaya karşı oluşan önyargı ve şüphenin tazmin edilip edilemeyeceği konusunda belirsizlik devam etmektedir. Marka hatasını telafi etmek için "Değişim Zamanı", "Sizi görüyor, duyuyor ve destekliyoruz", "Ses Yükselt”, "Ayağa Kalk", "Yeter", "Dayanıșma”, "Adalet", "Birlikte Yapabiliriz" ve "Bu Bir An Değil, Bu Bir Hareket” gibi \#blacklivesmatter'ı destekleyen ifadeler bulunan (Bakınız Şekil 4) tişörtler tasarlayarak gerçek bir destekçi olduğunu kanıtlamak istemiştir. Starbucks, yaptığı bu hata ve tutarsızlık sonucunda bu davranışını tazmin etme konusunda tasarladığı ve \#blacklivesmatter hareketini destekleyen ifadeler bulunan kıyafet ve aksesuarları çalışanlarına dağıtmıştır. Bu hareketi olumlu sonuç vermiş ve markanın hisseleri tekrar artış göstermiştir. Marka aktivizmi kuruluş açısından olumlu sonuçlar oluşturduğu kadar olumsuz sonuçları da beraberinde getirmektedir. Değişen tüketici profili markalardan sosyal, çevresel ve politik sorunlara karşı hassas bir yaklaşım göstermesini beklemekle birlikte aksi bir eylemde bulunan markaları da cezalandırmaktan çekinmemektedir.

\subsection{Netflix}

Dünya'nın en büyük dijital yayın platformlarından biri olan Netflix, Amerika Birleşik Devletleri'nde yaşanan \#blacklivesmatter protestolarına destek vererek marka aktivizmi hareketlerine dahil olmuştur. Kuruluş, siyahi vatandaş George Floyd'un polis müdahalesi esnasında hayatını kaybetmesi sonucu ülke çapında gerçekleştirilen protestoların ardından \#blacklivesmatter hareketine destek veren ilk medya ve eğlence şirketleri arasındadır. Netflix, 30 Mayıs 2020 tarihinde attığı tweette "Sessiz kalmak, suç ortağı olmaktır. Siyahların hayatları önemlidir. Bir platformumuz var ve siyahi üyelerimize, çalışanlarımıza ve yaratıcılarımıza karşı konuşmak için bir görevimiz var" diyerek \#blacklivesmatter hareketine destek verdiğini duyurmuştur (Bakınız Şekil 5). Tweet 1 milyondan fazla beğeni almış ve ayrıca 230.000 kişi tarafından da retweetlenmiștir (Variety, 2020a). Netflix'in, Şekil 5'teki gönderisinin altına "tüm hayatlar önemlidir" yorumlarının yanı sıra "tüm hayatlar önemlidir geri kalan her şey siyaset" yorumları da tüketiciler tarafından yazılmıștır. 


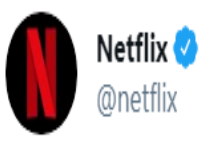

To be silent is to be complicit.
Black lives matter.

We have a platform, and we have a duty to our Black

members, employees, creators and talent to speak up.

Tweeti Çevir

ÖS 11:30 30 May 2020 - Twitter for Phone

209 B Retweet 9.824 Alinti Tweetler $1 \mathrm{Mn}$ Beğeni

Sekil 5

Kaynak: https://twitter.com/netflix/status/1266829242353893376

Netflix, \#blacklivesmatter hareketine dahil olduktan sonra bir başka tweet atarak "Siyahların hayatı önemlidir" dediğimizde aynı zamanda "Siyahların hikâye anlatımı önemlidir" demek istiyoruz. Gerçek, sistematik değişime olan bağlılığımızın zaman alacağını anlayarak, siyahi deneyimi hakkında güçlü ve karmaşık anlatıları vurgulayarak başlıyoruz (Bakınız Şekil 6) diyerek harekete verdiği desteği ön plana çıkarmıştır (Gomez, 2020). Polis şiddetine ve ırkçı ayrımcılığa son verilmesini talep eden küresel bir protesto dalgasının ardından dünyanın dört bir yanındaki insanlar rahatlık ve eğitim için ırkçılık karşıtı kitap, film, TV Show ve podcastlere yönelmektedir. Bu amaçla Netflix markası, sistematik ırkçılığı ve adaletsizliği açığa çıkaracak siyahi içerik oluşturucularının küratörlüğünü yaptığı filmler, belgeseller, diziler ve stand-uplardan oluşan bir \#blacklivesmatter başlıklı tür sekmesi eklemiştir (Seth, 2020). Netflix hikâye anlatıcılarını güçlendirmek ve siyahi deneyimlerini yansıtan film ve dizileri vurgulamak için 40'tan fazla yayın seçmiştir. Bir Netflix sözcüsü, Netflix markasının doğrudan olumlu bir etkiye sahip olmasının yollarından birinin hikayeleri olduğuna inandıklarını dile getirmiştir (Sutton, 2020).Marka, aynı zamanda \#blacklivesmatter kategorisindeki film ve dizileri 24 farklı sıralama yöntemine sahip tür sekmesinin altına koyarak dünya çapında izlenmesini sağlamıştır. Netflix, Amerika Birleşik Devletleri'nde irkçı adaletsizlik ve siyahi deneyiminden bahsederek bu başlıkları vurgulamanın empati ve anlayışı arttırmaya yardımcı olabileceğini umduklarını dile getirmiştir (Hibberd, 2020). Netflix'in hamlelerinin ardından 2011 yapımı "The Help" isimli film, Amerika Birleşik Devletleri'nde protestoların olduğu bir günde en çok izlenen film olmuştur. "The Help" filmi beyaz bir kurtarıcı karaktere odaklandığı gerekçesiyle birçok siyahi yazar ve aktivist tarafından eleştirilmiş ve kendilerini ırkçllı konusunda eğitmek için başka kaynaklar ve filmler aramaya yönelmişlerdir (Aquilina, 2020). Marka eleştirilere herhangi bir yanıt vermemiştir. Bunun sebebi ise "The Help" filminin \#blacklivesmatter etiketiyle öne çıkan filmlerden biri olmamasıydı. Marka, protestolar devam ederken Avustralyalı açık sözlü sanatçı Chris Lilley'in yer aldığı dört komedi şovunu Avustralya ve Yeni Zelanda'daki platformundan kaldırdı. Lilley'in şovlarındaki şüpheli karakter tasvirleri daha önce irk ayrımcılığı hakkındaki soruları gündeme getirmiști (Variety, 2020). Netflix, hareketinin 
en tepe noktasında olduğu dönemde tüm markalar arasından doğru adımlarıyla online cemiyetin beğenisini kazanmıştır. Online yayın platformu ırkçılık hakkında kendi marka değerleri ve kimliğiyle ters düşmeyecek türde programlar yayınlayarak hem eğitici hem de kullanıcılarının işine yarayacak içerikler sağlamıştır (Ocakoğlu, 2020).

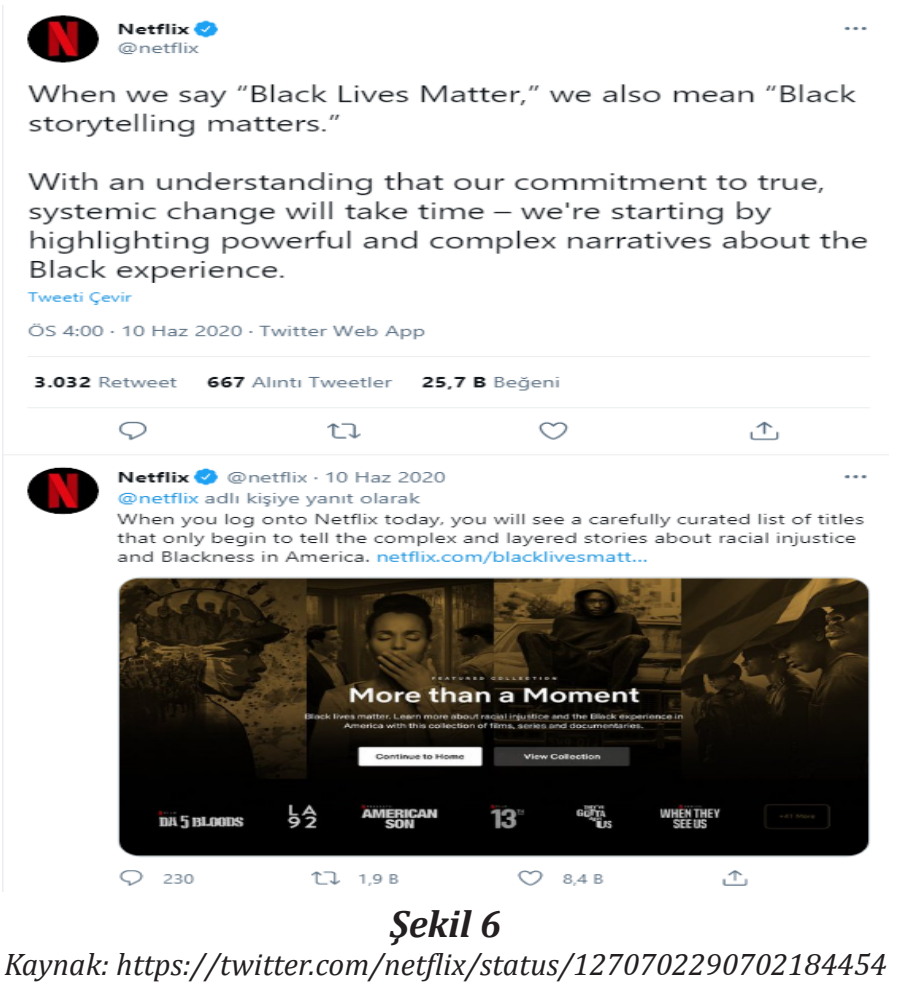

Netflix, \#blacklivesmatter hareketine dahil olarak tüketicilerinin yanında olduğunu hissettirmiş ve hassas bir duruş göstermiștir. Netflix'in bu davranışı, tüketiciler tarafından gayet olumlu karşılanmıștır. Netflix markası "The Help" filminden dolayı kısa süreli eleștirilere maruz kalsa da herhangi bir protesto ve boykot ile karşı karşı karşıya kalmamıștır. Netflix, harekete dahil olduktan sonra tüketicilerin ırkçı adaletsizlik ve eşitliğe karşı bilinçlenmesi için eklediği \#blacklivesmatter başlıklı tür sekmesi (Bakınız Şekil 6) ile tüketicilerden tam not almıştır. Avustralyalı sanatçı Chris Lilley'in içeriklerini kaldırarak tüketicilerin gözündeki imaj ve itibarını korumuş ve gerçekten \#blacklivesmatter destekçisi olduğunu kanıtlamıştır. Tüketicileri bilinçlendirme ve irkçı adaletsizliği önlemek için eğitim amaçlı yayınlarında herhangi bir kâr amacı gütmeyen ve tutarsız eylemlerde bulunmayan Netflix, \#blacklivesmatter hareketi kapsamında diğer markalara kıyasla başarılı olmuş markalardan bir tanesi olarak değerlendirilebilir.

\section{Sonuç ve Değerlendirme}

Marka aktivizmi, toplumda dikkat çekilmesi gereken ve tüketiciler açısından önemli olan konular üzerinde yoğunlaşmaktadır. Günümüzde tüketiciler markaların toplumsal, çevresel ve siyasal olaylar hakkında duruş göstermesini ve farkındalık yaratmalarını beklemektedir. Ayrıca tüketiciler markaların sorunlar hakkında hükümetlerden daha iyi fikirlere sahip olduklarını düşünmekte ve bu nedenle markaların sorunlara dahil olmaları gerektiğini belirtmektedir. Tüketicilerin bu tutumu karşısında markalar da yaşanan toplumsal, çevresel ve siyasal olaylar hakkında marka aktivizmi hareketlerine dahil olarak toplumun yanında olduğunu vurgulamaktadır. Günümüzde değişen tüketici profilleri nedeniyle artık ürün veya hizmetin fiyatından, kalitesinden veya fonksiyonlarından ziyade, markaların sorunlara bakış açısı, takındıkları tavır ve sergiledikleri duruş daha 
önemli hale gelmiştir. Bu sebeple marka aktivizmi, markalar ve tüketiciler nezdinde önemli bir kavram haline gelmiștir.

Marka aktivizmi, markanın tüketicinin gözünde imajının ve itibarının güçlenmesini sağlarken markalar açısından riskler de barındırmaktadır. Markalar, aktivizm hareketlerine dahil olduklarında, hareketin değerleriyle ters düșecek davranışlarda bulunmaları ya da tüketicilerde istemeden de olsa yanlış bir algı yaratmaları halinde eleştirilerle hatta boykotlarla karşı karşıya kalabilmektedir. Tüketiciler, markanın kâr amacı güttüğünü düşünerek markaya karşı şüpheci yaklaşmakta hatta markaya karşı nefret duymaktadır. Markalar, marka nefreti ve boykotlarla karşı karşıya kaldıklarında maddi olarak zarar görmelerinin yanı sıra imaj ve itibarları da zedelenmektedir.

Black lives matter hareketine dahil olan Nike markası ünlü NFL oyuncusu Colin Kaepernick'i kampanya yüzü yaparken büyük bir risk almıştır. Nike, \#blacklivesmatter hareketini desteklediğini duyurduktan sonra reklam yüzü olarak seçtiği Colin Kaepernick'i kara listeye alan NFL takımlarına sponsor olmaya devam ederek tüketicilerin şüphelerini üzerine çekmiştir. Bu olaylar sonucunda, hareketi desteklemeyen ve şüphe duyan tüketiciler tarafından protestolara ve boykotlara (Nike ürünlerinin yakılıp, parçalanması) maruz kalmasına rağmen pazardaki yerini koruyarak değerini de yükseltmiştir. Starbucks, \#blacklivesmatter hareketine destek verdiğini açıklamasının ardından harekete destek veren kıyafet ve aksesuar kullanımını yasaklamış ve tüketiciler tarafından büyük tepkilere maruz kalmıştır. Tepkiler, protestolar ve boykotlarla karşı karşıya kalan marka, çalışanlarının harekete destek veren kıyafet ve aksesuar kullanımını serbest bırakmıştır. Starbucks, yaptığı hata ve tutarsız davranışlarını düzeltmek için \#blacklivesmatter tişört ve aksesuarları tasarlayarak çalışanlarına dağıtmıştır. Yaptığı hatadan geç de olsa dönen marka, düşüşte olan hisselerini bir gün içinde tekrar yükseltebilmiştir. Netflix ise \#blacklivesmatter hareketine dahil olduktan sonra kendi platformunda \#blacklivesmatter başlığı altında bir tür sekmesi ekleyerek, hareketin doğrudan olumlu bir etkiye sahip olmasının yolunun hikayeler olduğunu vurgulamıştır. Marka bu davranışı ile ırkçı eşitsizlik ve siyahi deneyiminden bahsederek insanları bilinçlendirmek ve farkındalık yaratmak istemiștir. Netflix'in hareketi tüketiciler tarafından olumlu karşılansa da 2011 yılında yayınlanan bir içerik nedeniyle eleştirilere maruz kalmış ancak net bir duruş ve doğru adımlarla gerçek bir \#blacklivesmatter destekçisi olduğunu tüketicilere kanıtlamıştır. Markalar, aktivizm faaliyetlerinde tutarsız davranışlarda bulunmaları, tüketicilerde şüphe uyandırmaları ve istemeden de olsa yanlıș bir algıya sebebiyet vermeleri durumunda protesto ve boykotlarla karşı karşıya kalmaktadır. Aktivizm hareketinde bulunan markalar, destekledikleri hareketlerle tutarlı davranışlar sergilemeli ve şüphe yaratacak ifade ve eylemlerde bulunmamaları gerekmektedir. Marka aktivizmi, markalar açısından riskler barındırıyor olsa da doğru yapılan aktivizm hareketleri markanın değerini, imajını ve itibarını yükseltmektedir. Markalar, aktivizm hareketlerinde bulunmadan önce dikkatli olmalıdır. Tüketicinin bu eylemlere vereceği tepki her zaman net olmasa da marka bu noktada öngörü sahibi olabilmelidir. Bu sonuçlar doğrultusunda aktivizm hareketlerinde bulunacak kuruluşların tutarlı davranmaları, şüphe uyandıracak davranışlardan kaçınmaları, kâr amacı güderek hareketlere dahil olmamaları aktivizm hareketinin başarıya ulaşması noktasında çok önemlidir. 


\section{Kaynakça}

Adıyaman, T. (2020, Ağustos 10). Markaların sahibi yöneticiler değil insanlar! Ocak 5, 2021 tarihinde Marketing Türkiye: https://www.marketingturkiye.com.tr/ haberler/aktivist-markalar-cagi-basladi/ adresinden alındı

Al-Muslim, A. (2019, Ocak 17). Wsj. Aralık 28, 2020 tarihinde The Wall Street Journals: https://www.wsj.com/articles/gillettes-ad-with-a-metoo-edge-gets-mixedreactions-11547754187 adresinden alındı

Aquilina, T. (2020, Haziran 5). The Help becomes most-viewed movie on Netflix amid antiracism protests. Ocak 7, 2021 tarihinde Explore Entertainment: https://ew.com/ movies/the-help-most-viewed-movie-netflix-black-lives-matter-protests/ adresinden alındı

Aratani, L. (2020, Haziran 12). Starbucks reverses stance and allows staff to wear Black Lives Matter clothing. Ocak 5, 2021 tarihinde The Guardian: https://www. theguardian.com/business/2020/jun/12/starbucks-black-lives-matter-clothing adresinden alındl

Arklan, Ü., \& Kartal, N. Z. (2019). KURUMSAL SOSYAL SORUMLULUK VE AKTIVİZM: İLIŞKİSEL DÜZLEMDE EPISTEMOLOJIKK BİR YÖNELIMM. Süleyman Demiral Üniversitesi Vizyoner Dergisi, 10(23), 25-39. doi:https://doi.org/10.21076/ vizyoner.505651

Beydoun, K. A. (2018, Eylül 5). Nike just thrust Kaepernick back in the spotlight - where he belongs. Ocak 4, 2021 tarihinde The Guardian: https://www.theguardian.com/ commentisfree/2018/sep/05/colin-kaepernick-nike-ad-nfl-spotlight adresinden alındı

Bostock, B. (2018, Eylül 4). People are destroying their Nike shoes and socks to protest Nike's Colin Kaepernick ad campaign. Ocak 4, 2021 tarihinde Businessinsider: https://www.businessinsider.com/nike-advert-with-colin-kaepernick-haspeople-burning-products-2018-9 adresinden alındı

Bryson, D., Atwal, G., \& Hultén, P. (2013). Towards the conceptualisation of the antecedents of extreme negative affect towards luxury brands. Qualitative Market Research: An International Journal(16), 393-405.

Bulunmaz, B. (2014). YENİ MEDYA ESKİ MEDYAYA KARȘI: SAVAŞI KİM KAZANDI YA DA KIM KAZANACAK? Karadeniz Teknik Üniversitesi İletişim Araştırmaları Dergisi, 4(1), 22-29.

Canbaz, B. (2020, Ekim 20). Starbucks, Sosyal ve Irksal Eşitliği Geliştirmek İçin Bir Dizi Standart Belirledi. Ocak 6, 2021 tarihinde Pazarlamasyon: https://pazarlamasyon. com/starbucks-sosyal-ve-irksal-esitligi-gelistirmek-icin-bir-dizi-standartbelirledi/ adresinden alındı

Carp, C. (2018, Mart 28). NFL confirms long-term extension with Nike. Ocak 4, 2021 tarihinde Sportsmedia: https://www.sportspromedia.com/news/nfl-nikeuniform-deal adresinden alındı

Chadwick, S., \& Zipp, S. (2018, Eylül 14). Nike, Colin Kaepernick and the pitfalls of 'woke' corporate branding. Ocak 4, 2021 tarihinde TheConversation: https:// theconversation.com/nike-colin-kaepernick-and-the-pitfalls-of-woke-corporatebranding-102922 adresinden alındı 
Chibita, M. B. (2016). Digital Activism in Uganda. B. Mutsvairo (Dü.) içinde, Digital Activism in the Social Media Era, Critical Reflections on Emerging Trends in SubSaharan Africa (s. 69-95). İngiltere: Palgrave Macmillan.

Creswell, J. W. (2013). Nitel Araştırma Yöntemleri (3. Baskıdan Çeviri b.). (M. Bütün, \& S. B. Demir, Çev.) Ankara: Siyasal Kitapevi.

Edelman. (2018, Ekim 2). TWO-THIRDS OF CONSUMERS WORLDWIDE NOW BUY ON BELIEFS. Aralı 12, 2020 tarihinde Edelman: https://www.edelman.com/newsawards/two-thirds-consumers-worldwide-now-buy-beliefs adresinden alındı

Fidan, B. (2017, Mayıs). Dur! Brandmap(13), s. 40-46.

Friedman, M. (1999). Consumer Boycotts: Effecting Change Through the Marketplace and the Media. London, Birleşik Krallık: Routledge.

Garcia, T. (2020, Haziran 12). Starbucks reverses policy to allow workers to wear Black Lives Matters apparel. Ocak 5, 2021 tarihinde Marketwatch: https://www. marketwatch.com/story/starbucks-reverses-policy-to-allow-workers-to-wearblack-lives-matters-apparel-2020-06-12?mod=article_inline adresinden alındı

Gomez, D. (2020, Haziran 10). Netflix adds Black Lives Matter collection as its own genre. Ocak 6, 2021 tarihinde latimes: https://www.latimes.com/entertainment-arts/ tv/story/2020-06-10/netflix-curates-black-lives-matter-collection adresinden alındı

Green, D. (2018, Eylül 5). Trump tweets that Nike is 'getting absolutely killed with anger and boycotts' over its Colin Kaepernick ad. Ocak 4, 2021 tarihinde Businessinsider: https://www.businessinsider.com/trump-tweet-nike-boycott-colin-kaepernickad-2018-9 adresinden alındı

Guardian Sport. (2019, Eylül 16). Nike's 'Dream Crazy' advert starring Colin Kaepernick wins Emmy. Ocak 4, 2021 tarihinde The Guardian: https://www.theguardian.com/ sport/2019/sep/16/nikes-dream-crazy-advert-starring-colin-kaepernick-winsemmy adresinden alındı

Hegner, S., Fetscherin, M., \& Delzen, M. v. (2017). Determinants and outcomes of brand hate. Journal of Product \& Brand Management, 1(26), 13-25. doi:0.1108/JPBM-012016-1070

Hibberd, J. (2020, Haziran 10). Netflix adds Black Lives Matter as a new genre after The Help concerns. Ocak 7, 2021 tarihinde Explore Entertainment: https://ew.com/tv/ netflix-black-lives-matter-genre/ adresinden alındı

Ikea Youtube. (2018). The IKEA Climate Change Effect. Aralık 28, 2020 tarihinde www. youtube.com: https://www.youtube.com/watch?v=2IxHqtQj1rU adresinden alındı

Joyce, M. (2010). Introduction: How to Think About Digital Activism. M. Joyce (Dü.) içinde, Digital Activism Decoded The New Mechanics of Change (s. 1-14). New York: International Debate Education Association.

Klein, J. G., Smith, N. C., \& John, A. (2004). Why We Boycott: Consumer Motivations for Boycott Participation. Journal Of Marketing, 3(68), 92-109. doi:https://doi. org/10.1509/jmkg.68.3.92.34770 
Kotler, P., \& Sarkar, C. (2017, Ocak 9). "Finally, Brand Activism!” - Philip Kotler and Christian Sarkar. Aralık 12, 2020 tarihinde The Marketing Journal: https://www. marketingjournal.org/finally-brand-activism-philip-kotler-and-christian-sarkar/ adresinden alındı

Kubiak, K., \& Ouda, S. (2020). Brand Activism-The Battle Between Authenticity and Consumer Scepticism (Yüksek Lisans Tezi). Lund University.

Manfredi-Sánchez, J. L. (2019). Brand activism. Communication \& Society, 4(32), 343-359. doi:10.15581/003.32.4.343-359

Marketing Charts. (2019, Aralık 16). Consumers Are Skeptical When Brands Take A Stand. How Can They Boost Credibility? Aralık 12, 2020 tarihinde Marketing Charts: https://www.marketingcharts.com/brand-related/csr-111308 adresinden alındı

Naik, U., \& Shivalingaiah, D. (2009). Comparative Study of Web 1.0, Web 2.0 and Web 3.0. Conference: 6th International CALIBER 2008 At: University of Allahabad, Allahabad. Allahabad: University of Allahabad. doi:10.13140/2.1.2287.2961

Ocakoğlu, D. S. (2020, Ağustos 13). Marka aktivizmi ne değildir? Ocak 7, 2021 tarihinde Marketing Türkiye: https://www.marketingturkiye.com.tr/haberler/markaaktivizmi-ne-degildir/ adresinden alındı

Odabașı, Y. (2013). Siyasallaşan Tüketici, Tuketim ve Marka Yönetimi. Brand Age(54), s. 26-29.

Odabaşı, Y. (2020). Postmodern Pazarlamayı Anlamak. İstanbul: Thekitap Yayınları.

Reints, R. (2018, Eylül 23). Colin Kaepernick Pushes Nike’s Market Value Up \$6 Billion, to an All-Time High. Ocak 4, 2021 tarihinde Fortune: https://fortune. com/2018/09/23/nike-market-value-colin-kaepernick-ad/ adresinden alındı

Ritschel, C. (2019, Ocak 17). Independent. Aralık 28, 2020 tarihinde Independent: https://www.independent.co.uk/life-style/gillette-ad-commercial-pink-taxcontroversy-toxic-masculinity-metoo-a8731821.html adresinden alındı

Sack, B., \& Samaha, A. (2020, Haziran 10). Starbucks Won't Let Employees Wear Gear That Supports Black Lives Matter Because It Is Political Or Could Incite Violence. Ocak 5, 2021 tarihinde Buzzfeednews: https://www.buzzfeednews.com/ article/briannasacks/starbucks-is-now-very-pro-black-lives-matter-but-it-wont adresinden alındı

Sarkar, C., \& Kotler, P. (2018). Brand Activism: From Purpose to Action. USA: Idea Bite Press.

Segran, E. (2020, Haziran 6). Starbucks banned employees from wearing BLM T-shirts. Now it's making its own. Ocak 5, 2021 tarihinde Fastcompany: https://www. fastcompany.com/90516865/starbucks-banned-employees-from-wearing-blm-tshirts-now-its-designing-its-own adresinden alındı

Seth, R. (2020, Haziran 18). 5 Necessary Releases To Watch From Netflix's New Black Lives Matter Section. Ocak 7, 2021 tarihinde Vogue: https://www.vogue.co.uk/arts-andlifestyle/article/black-lives-matter-netflix adresinden alındı 
Shetty, S., Venkataramaiah, N. B., \& Anand, K. (2019). Brand activism and millennials: an empirical investigation into the perception of millennials towards brand activism. Problems and Perspectives in Management, 4(17), 163-175. doi:10.21511/ ppm.17(4).2019.14

Sivitanides, M., \& Shah, V. (2011). The Era of Digital Activism. Conference for Information Systems Applied Research, (s. 1-8). Wilmington North Carolina, USA.

Subaşı, M., \& Okumuş, K. (2017). Bir Araştırma Yöntemi Olarak Durum Çalışması. Atatürk Üniversitesi Sosyal Bilimler Enstitüsü Dergisi, 21(2), 419-426.

Sutton, K. (2020, Haziran 10). Netflix Releases Black Lives Matter Collection as Streamers Highlight Black Storytelling. Ocak 7, 2021 tarihinde Adweek: https://www. adweek.com/convergent-tv/netflix-releases-black-lives-matter-collection-asstreamers-highlight-black-storytelling/ adresinden alındı

Şekil 1. (2018, Eylül 3). Nike Twitter Gönderisi. Ocak 4, 2021 tarihinde https://twitter. com/Kaepernick7/status/1036695513251434498 adresinden alındı

Şekil 2. (2020). Nike Twitter Resmi Hesap. Ocak 5, 2021 tarihinde https://twitter.com/ Nike adresinden alındı

Şekil 3. (2020, Haziran 4). Starbucks Twitter Gönderisi. Ocak 5, 2021 tarihinde https:// twitter.com/Starbucks/status/1268513794172411905 adresinden alındı

Şekil 4. (2020, Haziran 12). Starbucks Twitter Gönderisi. Ocak 5, 2021 tarihinde https:// twitter.com/Starbucks/status/1271440942591913986 adresinden alındı

Şekil 5. (30, Mayıs 2020). Netflix Twitter Gönderisi. Ocak 4, 2021 tarihinde https:// twitter.com/netflix/status/1266829242353893376 adresinden alındı

Şekil 6. (2020, Haziran 10). Netflix Twitter Gönderisi. Aralık 29, 2020 tarihinde https:// twitter.com/netflix/status/1270702290702184454 adresinden alındı

Tuna, Ö., \& Besler, S. (2015). KURUMSAL SÜRDÜRÜLEBİLİRLİK ANLAYIŞI VE UYGULAMALARI: ÖRNEK OLAY ÇALIŞMASI. İstanbul Üniversitesi Siyasal Bilgiler Fakültesi Dergisi, 0(52), 173-199.

Turhan, D. G. (2017). DİjİTAL AKTIVİZM. Süleyman Demirel Üniversitesi Sosyal Bilimler Enstitüsü Dergisi(26), 26-44.

Uhler, A. (2020, Haziran 25). Nike's brand burnished by its affiliation with Colin Kaepernick. Ocak 4, 2021 tarihinde Marketplace: https://www.marketplace. org/2020/06/25/nike-colin-kaepernick-brand-advertising-racial-justice/ adresinden alındı

Ürkmez, D. (2020). Dijital Aktivizm Olarak Sosyal Medyada Boykot Çağrıları: Watsons Krizi Örneği. İstanbul Gelişim Üniversitesi Sosyal Bilimler Dergisi, 7(1), 106-125. https://doi.org/10.17336/igusbd.541514

Variety. (2020a, Haziran 10). Netflix Launches 'Black Lives Matter' Collection of Movies, TV Shows and Documentaries. Ocak 6, 2021 tarihinde Variety: https://variety. com/2020/digital/news/netflix-black-lives-matter-collection-1234630160/ adresinden alındı 
Variety. (2020, Haziran 10). Netflix Permanently Pulls Four Chris Lilley Shows Over Racial Depictions. Ocak 7, 2021 tarihinde Variety: https://variety.com/2020/ streaming/asia/netflix-removes-chris-lilley-shows-racial-depiction-1234630169/ adresinden alındı

Vredenburg, J., Kapitan, S., Spry, A., \& Kemper, J. (2020). Brands Taking a Stand: Authentic Brand Activism or Woke Washing? Journal of Public Policy \& Marketing, 4(39), $1-50$.

Zarantonello, L., Romani, S., Grappi, S., \& Bagozzi, R. (2016). Brand hate. Journal of Product \& Brand Management, 1(25), 1-42. https://doi.org/10.1108/JPBM-012015-0799 


\title{
To Support or Not (Be Able) to Support: An Evaluation in the Context of Brand Activism
}

\author{
Ömer Aydınlıoğlu (Asst. Prof. Dr.) \\ Mert Susur (MA Student)
}

\section{Extended Abstract}

Gathering together helped humankind to survive from the very beginning of the history up to now. Building community and acting as a community is important for the humankind, a social creature as they provide advantage and gain victory against severe natural conditions, wild animals and enemies. Therefore, as the time lapses, human being started to display behaviour of acting as a community against other humans, circumstances and institutions that are dissatisfying and required to be corrected. Even though the history of activist movements dates back to ancient times, the history of brand activism is quite novel. Brand activism which is defined as consumers taking action to raise awareness or support the brands about a specific issue is a common action today. Especially, brand activism movements that are launched on social media platforms move so fast. On the other hand, consumers follow the brands closely and they expect and demand the brands to act sensibly. The brands involved in brand activism movements enable consumers to be sceptic. Furthermore, consumers hate the brands that display incoherent behaviours, do wrong or create a negative perception related to a social issue. The consumers that are sceptic about the brands do not believe in them and are of the opinion that they seek for profit. In case of having brand hate towards a brand, the consumer wants to punish the brand and avoid its products /services. The brands that do not please the consumers or annoy them are boycotted and lynched within minutes through social media platforms. The studies demonstrate that consumers reward the brands that prove their sensitivity to social issues. Similarly, the brands that do wrong or cause a negative perception are boycotted in either real or virtual environments. Recently, the death tolls caused by the unproportioned police force and violence against the black people have drawn both citizens' and the businesses' attention in the USA. While some globally known brands donated high quantity of money to the funds or charities under the hashtag of \#blacklivesmatter, some other global brands post several messages on purpose to support and raise awareness on social platforms. These supportive actions are perceived by the consumers as if the brands are getting involved in politics and therefore, they are boycotted on social media platforms. The aim of this study is to evaluate and discuss the global brands' support to the \#blacklivesmatter movement and the reflections of this support on consumers in detail. In this sense, the sample of the study includes brands like Nike, Starbucks and Netflix that support \#blacklivesmatter movement and accused of taking part in politics on digital platforms. The brands and their activist actions are evaluated through case study technique.

Nike was considered as a suspicious brand by the consumers because of its incompatible actions. As the consumers are unsure of the brands' actions, they thought that it pokes into politics and seeks for profit in its activism movements. Thus, Nike was boycotted by the consumers in social media. Besides, the products of Nike were burned by the angry customers during the protests. Although Nike was exposed to consumer scepticism and boycotts, its marketing value and shares surprisingly increased. Starbucks was exposed to protests and boycotts because it prohibited to wear t-shirts and accessories that have 
the logo of movement in its stores after declaring their support to \#blacklivesmatter movement. As a result of consumer reactions, the brand designed t-shirts that have supportive statements about the movement. They accepted their faults and handed in the t-shirts to their employees. The action turned back to brand as an increase in its share proportions. Netflix declared their support to the movement via social media platforms and added a type section that includes the programmes which support \#blacklivesmatter movement. Although the brand got positive reactions from the consumers, it was also criticized for a while because of a program that was released in 2011. Netflix removed the contents of Chris Lilley from the platform and put an end to this problem. Netflix proved to be a supporter of the movement and accomplished to protect its reputation and image among its customers and therefore did not come across any boycott or protest.

In conclusion, brand activism may both be beneficial or detrimental to the brands. The brands which take action in brand activism movement had better foresee the consumer reactions related to the movement. Besides, they should abstain from the actions which are not compatible with the activism such as doing wrong or having a negative impression on the consumers.

Keywords: Brand Activism, Activism, Boycott, Brand Hate, \#blacklivesmatter.

Bu makale intihal tespit yazııımlarıyla taranmıştır. Intihal tespit edilmemiştir.

This article has been scanned by plagiarism detection softwares. No plagiarism detected.

Bu çalışmada "Yükseköğretim Kurumları Bilimsel Araştırma ve Yayın Etiği Yönergesi" kapsamında uyulması belirtilen kurallara uyulmuştur.

In this study, the rules stated in the "Higher Education Institutions Scientific Research and Publication Ethics Directive" were followed.

Yazarların çalışmadaki katkı oranları eşittir.

The authors' contribution rates in the study are equal.

Çalışma kapsamında herhangi bir kurum veya kişi ile çıkar çatışması bulunmamaktadır.

There is no conflict of interest with any institution or person within the scope of the study. 